\title{
PENGARUH PELATIHAN DAN MOTIVASI TERHADAP KINERJA KARYAWAN SERTA KINERJA ORGANISASI KEMENTERIAN KOMUNIKASI DAN INFORMATIKA
}

\author{
Anriza Julianry ${ }^{*}$, Rizal Syarief ${ }^{* *}$, dan M. Joko Affandi $\left.{ }^{* * *}\right)$ \\ *) Sekolah Bisnis, Institut Pertanian Bogor \\ Jl. Raya Pajajaran, Bogor 16151 \\ **) Departemen Ilmu dan Teknologi Pangan, Fakultas Teknologi Pertanian, Institut Pertanian Bogor \\ Kampus IPB Darmaga, Jl. Lingkar Akademik, Jawa Barat 16680 \\ $\left.{ }^{* * *}\right)$ PPM Manajemen \\ Jl. Menteng Raya 9, Jakarta 10340
}

\begin{abstract}
The level of knowledge, skills and motivation of the Keminfo employees in improving their performance can affect the organization's ability to improve productivity and this is associated with the assessment of Government Agencies Performance Accountability Report (LAKIP) by the Ministry of Administrative Reform (minister). The objectives of this research were to identify, understand and analyze the effect of training and motivation on the employee performance and organization performance of Keminfo. This research was an explanatory study. The latent variables were training and motivation, while the observed variables were employee performance and organizational performance. The data collection technique was by interviews, and the researchers also gathered information through questionnaires using the Likert scale. The researchers tested the reliability of the data obtained and then used the descriptive analysis and Structural Equation Model (SEM). From the results of data analysis, it can be seen that training variable significantly has positive effect on employee performance but a negative effect on the performance organization. Motivation variable has negative effect on employee performance but a positive one on organizational performance, Training variable has a positive effect on the motivation and performance of employees, and it also significantly affects the overall performance of the organization.
\end{abstract}

Keywords: education and training, employee performance, motivation, organizational performance, SEM

\begin{abstract}
ABSTRAK
Tinggi rendahnya pengetahuan, keterampilan dan motivasi kerja karyawan Keminfo dalam meningkatkan kinerja karyawannya serta dapat memengaruhi kemampuan organisasi dalam meningkatkan produktivitasnya dan hal ini berhubungan dengan penilaian Laporan Akuntabilitas Kinerja Instansi Pemerintah (LAKIP) oleh Kementrian Pendayagunaan Aparatur Negara (Menpan). Tujuan penelitian ini adalah mengetahui dan memahami serta menganalisis pengaruh dari pelatihan dan motivasi terhadap kinerja karyawan dan kinerja organisasi Keminfo. Penelitian ini bersifat konfirmatory. Variabel latennnya adalah pelatihan dan motivasi, sedangkan untuk variabel teramatinya adalah kinerja karyawan dan kinerja organisasi. Teknik pengumpulan data yang dilakukan adalah dengan interview, peneliti juga menghimpun informasi melalui kuesioner yang mengunakan skala Likert. Peneliti melakukan uji reliabilitas terhadap data yang diperoleh dan selanjutnya menggunakan analisis deskriptif dan analisis Structural Equation Model (SEM). Dari hasil analisis data dapat diketahui variabel pelatihan secara signifikan berpengaruh positif terhadap kinerja karyawan akan tetapi berpengaruh negative terhadap kinerja organisasi.Untuk variabel motivasi berpengaruh negative terhadap kinerja karyawan akan tetapi berpengaruh positif terhadap kinerja organisasi, Sedangkan untuk variabel pelatihan berpengaruh positif terhadap motivasi serta kinerja karyawan juga signifikan berpengaruh terhadap kinerja organisasi secara keseluruhan.
\end{abstract}

Kata kunci: kinerja karyawan, kinerja organisasi, motivasi, pelatihan, SEM

\footnotetext{
${ }^{1}$ Alamat Korespondensi:

Email:anriza21@gmail.com
} 


\section{PENDAHULUAN}

Pada era reformasi ini dan dampak persaingan global mendorong percepatan perubahan perbaikan kinerja aparatur pemerintah. Masalah Sumber Daya Manusia (SDM) saat ini masih tetap menjadi pusat perhatian bagi suatu perusahaan untuk bertahan di era globalisasi yang diiringi dengan tingkat persaingan yang semakin ketat (Budiartha et al. 2015). SDM di dalam organisasi erat kaitannya dengan strategi organisasi secara menyeluruh serta perencanaan SDM yang baik (Radhian, 2016). Sumber daya manusia yang handal merupakan salah satu faktor yang dibutuhkan di era globalisasi (Rumondor, 2013). Aparatur pemerintah dituntut bekerja lebih profesional, bermoral, bersih dan beretika dalam mendukung reformasi birokrasi dan menunjang kelancaran tugas pemerintahan dan pembangunan serta meningkatkan kinerja. Saat ini, kualitas kinerja pegawai negeri sipil di Indonesia masih belum dapat dikatakan baik secara keseluruhan (Pakpahan et al. 2014). Indikator yang memiliki kontribusi paling besar terhadap budaya perusahaan adalah profesional, inovasi, dan team work (Ernanto et al. 2015). Investasi manusia merupakan investasi paling penting yang dapat dilakukan oleh organisasi yang tujuannya bermuara pada satu titik akhir yaitu agar organisasi memiliki sejumlah tenaga kerja yang bermutu, disiplin kerja, dedikasi, loyalitas, persepsi, efisiensi, efektifitas kerja dan produktivitas kerja dapat memenuhi kebutuhan organisasi, tidak hanya untuk masa kini akan tetapi untuk masa depan (Satria, 2013). Untuk dapat membentuk sosok Pegawai Negeri Sipil (PNS) seperti itu perlu dilaksanakan pembinaan melalui jalur Pelatihan yang mengarah pada upaya peningkatan sikap dan semangat pengabdian, kompetensi dan efisiensi, efektifitas, serta kualitas pelaksanaan tugas yang dilakukan. Isi dari suatu tugas atau pekerjaan merupakan dasar tetap untuk merumuskan sasaran yang akan dicapai dari suatu tugas utama yang dapat dirumuskan sebagai target kuantitas, standar kinerja suatu tugas atau proyek tertentu untuk diselesaikan (Rivai dan Basri, 2005). Undang-undang Republik Indonesia Nomor 5 tahun 2014 tentang Aparatur Sipil Negara, pasal 77 menyebutkan bahwa hasil penilaian kinerja Pegawai Negeri Sipil (PNS) digunakan untuk menjamin objektivitas dalam pengembangan PNS dan dijadikan sebagai persyaratan dalam pengangkatan jabatan dan kenaikan pangkat, pemberian tunjangan dan sanksi, mutasi, dan promosi, serta untuk mengikuti pelatihan.
Dalam rangka menghadapi tuntutan dan tugas sekarang dan terutama untuk menjawab tantangan masa depan, pendidikan dan pelatihan merupakan suatu keharusan (Rapaeni, 2013). Pengembangan yang dilakukan Kementrian Komunikasi dan Informatika (Keminfo) melalui pelatihan merupakan suatu usaha untuk meningkatkan kualitas karyawannya. Program pelatihan yang dilakukan dengan baik akan mempunyai pengaruh terhadap kinerja karyawan (Pojoh et al. 2014). Tuntutan bahwa karyawan harus bekerja dengan tingkat kinerja yang tinggi atau sekedar agar mampu berkreatifitas dan berinovasi tidak hanya pada pemberian knowledge melalui pelatihan saja, tetapi motivasi juga penting untuk merangsang karyawan agar lebih berprestasi lagi. Pemberian motivasi dan kebebasan kepada karyawan untuk merampungkan pekerjaannya sesuai dengan bidang tugasnya dapat membuat kinerja karyawan lebih optimal dalam mengekplorasi potensi yang dimiliki. Tinggi rendahnya pengetahuan, keterampilan dan motivasi kerja karyawan Keminfo dalam meningkatkan kinerja karyawannya serta dapat memengaruhi kemampuan organisasi dalam meningkatkan produktivitasnya. Hal ini berhubungan dengan penilaian Laporan Akuntabilitas Kinerja Instansi Pemerintah (LAKIP) oleh Kementrian Pendayagunaan Aparatur Negara (Menpan). Dari hasil evaluasi Laporan Kinerja Kemenpan (Tabel 1), nilai rata-rata untuk kementerian/ lembaga meningkat, dari 64,70 pada tahun 2014 menjadi 65,82 pada tahun 2015. Nilai rata-rata untuk pemerintah provinsi meningkat dari 59.21 pada tahun 2014 menjadi 60.47 pada tahun 2014. Nilai tersebut menunjukkan tingkat akuntabilitas atau pertanggungjawaban atas hasil (outcome) terhadap penggunaan anggaran dalam rangka terwujudnya pemerintahan yang berorientasi kepada hasil (result oriented government).

Tabel 1. Nilai Akuntabilitas kinerja Kementerian dan Lembaga Tahun 2014

\begin{tabular}{|c|c|c|c|}
\hline Peringkat & Instasi Pusat & Nilai 2014 & Predikat \\
\hline 1 & $\begin{array}{l}\text { Kementerian } \\
\text { Keuangan }\end{array}$ & 83,59 & A \\
\hline 2 & $\begin{array}{l}\text { Komisi Pemberatas } \\
\text { Korupsi }\end{array}$ & 80,89 & A \\
\hline 47 & $\begin{array}{l}\text { Kementerian } \\
\text { Komunikasi dan } \\
\text { Informatika }\end{array}$ & 64,35 & B \\
\hline 85 & $\begin{array}{l}\text { Pepustakaan } \\
\text { Nasional }\end{array}$ & 50,38 & $\mathrm{CC}$ \\
\hline 86 & Kejaksaan Agung & 50,02 & $\mathrm{CC}$ \\
\hline
\end{tabular}


Pada dasarnya pelatihan merupakan proses yang berlanjut dan bukan proses sesaat saja terutama disaat perkembangan teknologi dan pengetahuan berkembang pesat seperti saat ini, peran pendidikan dan pelatihan sangat besar peranannya untuk membekali karyawan agar lebih kreatif dalam mencapai tujuan perusahaan secara efektif dan efisien (Fatihin, 2014). Pelaksanaan pendidikan dan pelatihan ditujukan untuk peningkatan penguasaan akan ketrampilan dan pengetahuan karyawan dalam upaya peningkatan kinerja (Dartha, 2010). Pendidikan dan pelatihan menekankan peningkatan keterampilan ataupun kemampuan dalam human relation (Martoyo, 1992).

Motivasi menurut Mangkunegara (2009) merupakan dorongan yang muncul dalam diri seseorang baik karena faktor internal maupun eksternal yang menggerakannya untuk melakukan sesuatu demi mencapai tujuan. Motivasi kerja berpengaruh positif dan nyata terhadap kepuasan kerja karyawan (Suryana et al. 2010). Tinggi rendah pengetahuan, keterampilan dan kepuasan kerja karyawan Kemeninfo dalam meningkatkan kinerjanya dapat memengaruhi kemampuan Kementerian khususnya pusdiklat dalam meningkatkan produktivitasnya dan hal ini berhubungan dengan penilaian LAKIP oleh Menpan. Motivasi akan memberikan kesempatan kepada karyawan untuk meningkatkan gairah dan semangat kerja karyawan (Dewi dan Laras, 2014). Pelatihan bagi karyawan merupakan sebuah proses mengajarkan pengetahuan dan keahlian tertentu serta sikap agar karyawan semakin terampil dan mampu melaksanakan tanggungjawabnya dengan semakin baik, sesuai dengan kapasitasnya masing-masing (Sahanggamu, 2014). Pengetahuan, keterampilan dan motivasi ini merupakan nilai-nilai yang harus diinternalisasi kepada seluruh karyawan agar karyawan menyadari bahwa mereka adalah tenaga-tenaga kerja terampil yang dibutuhkan untuk kemajuan perusahaan. Di satu sisi perbaikan efektivitas dan efisiensi melalui peningkatan pengetahuan dan keterampilan karyawan dapat dilakukan melalui program pendidikan dan latihan (diklat), sedangkan pada sisi lain peningkatan sikap karyawan terhadap pekerjaan serta tugas-tugasnya dapat dilakukan dengan usaha memotivasi para karyawan (Setiana dan Siswandoko, 2009).

Menurut Hersey and Blanchard (1993) kinerja adalah suatu fungsi dari motivasi dan kemampuan untuk menyelesaikan tugas atau pekerjaan, seseorang harus memiliki derajat kesediaan dan tingkat kemampuan tertentu. Kinerja seseorang dapat dilihat dari usaha usaha dari karyawan untuk menyelesaikan tugasnya, keterampilan yang dimiliki untuk menyelesaikan pekerjaannya (Nazar et al. 2014). Semakin baik kinerja seorang pegawai, berarti pegawai tersebut juga semakin produktif atau produktivitas kerjanya semakin meningkat (Yusuf, 2015).

Kinerja organisasi menurut Sobandi (2006) merupakan sesuatu yang telah dicapai oleh organisasi dalam kurun waktu tertentu, baik yang terkait dengan input, output, outcome, benefit, maupun impact. Kinerja organisasi diperlukan untuk memahami dan meningkatkan pencapaian sasaran dan tujuan organisasi yang optimal good coorporate governance (GCG). Kinerja karyawan tidak hanya berasal dan datang dari dalam diri karyawan itu sendiri, tetapi juga dipengaruhi oleh faktor di luar diri. Penelitian ini dibuat untuk meneliti kedua hal tersebut, yaitu pelatihan dan motivasi kerja karyawan. Sejauh mana pengaruh pelatihan dan motivasi kerja terhadap kinerja karyawan dan juga dampaknya terhadap kinerja organisasi yang dalam hal ini adalah Kementerian Komunikasi dan Informatika. Faktor-faktor yang dijadikan ukuran kinerja menurut pendapat Keith dan Newstrom (2000) adalah faktor kemampuan (ability) dan faktor motivasi (motivation), yaitu Human performance $=$ Ability + Motivation .

Beberapa penelitian yang menyinggung beberapa hal yang dibahas dalam penelitian ini. Penelitian yang dilakukan melanjutkan penelitian dari Helmi (2003), dengan judul Pengaruh Pelatihan dan Pengembangan Serta Prestasi Kerja terhadap Pengembangan Karir Karyawan Pada PT Perkebunan Nusantara III (Persero) Medan. Hasil penelitian adalah terdapat pengaruh yang signifikan antara prestasi kerja dengan pengembangan karir karyawan. Penelitian ini dilakukan untuk mengetahui, memahami dan menganalisis pengaruh pelatihan serta motivasi terhadap kinerja karyawan dan kinerja organisasi.

Berdasarkan permasalahan dan penelitian terdahulu maka tujuan penelitian ini adalah mengetahui dan memahami serta menganalisis pengaruh dari pelatihan dan motivasi terhadap kinerja karyawan dan kinerja organisasi Keminfo. 


\section{METODE PENELITIAN}

Pada penelitian ini, populasi adalah karyawan yang telah mengikuti pelatihan oleh Keminfo. Jumlah populasi yang tercatat pada Laporan Kinerja Keminfo tahun 2015 adalah sebesar 7.575 orang. Teknik pengambilan sampel menggunakan sampling acak sederhana (Simple Random Sampling). Random sampling adalah metode paling dekat dengan definisi probability sampling. Pengambilan sampel dari populasi secara acak berdasarkan frekuensi probabilitas semua anggota populasi. Jumlah sampel penelitian ini adalah 100 orang karyawan, Karyawan yang dimaksud adalah karyawan dan karyawati yang telah mengikuti pelatihan pada tahun 2014

Penelitian ini bersifat explanatory study, yaitu penelitian yang bertujuan menelaah kausalitas antar variabel dan menjelaskan suatu fenomena tertentu. Format eksplanasi adalah menggambarkan suatu generalisasi atau menjelaskan hubungan antar satu variabel dengan variabel yang lainnya. Oleh karena itu, penelitian eksplanatif menggunakan pengujian hipotesis berupa statistik inferensial. Berdasarkan penelitian yang menjelaskan dan menguji hipotesis, penelitian ini menggunakan pendekatan kuantitatif dengan memakai deskriptif statistik inferensial.

Selain interview, penulis juga menghimpun informasi melalui kuesioner yang menggunakan skala Likert. Proses pengolahan data meliputi kegiatan entry data, editing, coding, scoring, dan cleaning data. Sebelum melakukan analisis lanjutan, peneliti melakukan uji reliabilitas terhadap data yang diperoleh. Selanjutnya peneliti menggunakan analisis deskriptif dan analisis Structural Equation Model (SEM) dengan software LISREL. Analisis SEM dapat memberikan analisis yang berbasis pada Confirmatory Factor Analysis (CFA) suatu model yang menggabungkan analisis korelasi, analisis regresi, analisis lintas, dan analisis faktor (Suharjo, 2007). Pada tahap ini kesesuaian model dievaluasi melalui telaah terhadap berbagai kriteria Goodness of fit seperti pada Tabel 2.

Pengujian kesesuaian model (goodness of fit) dengan uji khi kuadrat dilakukan dengan cara memperbandingkan antara matriks kovarians hasil dugaan dengan martriks kovarians data observasi. Model pengukuran penelitian ini dapat dilihat pada Gambar 1. yang mengukur hubungan antara variabel indikator dengan konstruk.
Tabel 2. Kriteria Goodness of fit Model Overall

\begin{tabular}{|c|c|}
\hline Goodness of fit & Keterangan \\
\hline Chi-Square (x2) & $\begin{array}{l}\text { Semakin kecil semakin baik. } \\
\text { Digunakan nilai Chi-Square } \\
\text { yang kecil agar } \mathrm{H} 0: \sum=\sum(0) \text {, } \\
\text { tidak ditolak }\end{array}$ \\
\hline $\begin{array}{l}\text { Root Mean Square } \\
\text { Residual (RMR) }\end{array}$ & Digunakan untuk $\mathrm{n}$ besar \\
\hline $\begin{array}{l}\text { Root Mean Square } \\
\text { Error Approximation } \\
\text { (RMSEA) }\end{array}$ & $\begin{array}{l}\text { Nilai aproksimasi akar rata-rata } \\
\text { kuadrat error }\end{array}$ \\
\hline $\begin{array}{l}\text { Goodness of fit Index } \\
\text { (GFI) }\end{array}$ & Mirip dengan $\mathrm{R} 2$ dalam regresi \\
\hline $\begin{array}{l}\text { Adjusted Goodness of } \\
\text { fit Index (AGFI) }\end{array}$ & $\begin{array}{l}\text { Mirip dengan R2-adjusted dalam } \\
\text { regresi }\end{array}$ \\
\hline $\begin{array}{l}\text { Normed Fit Index } \\
(\mathrm{NFI})\end{array}$ & $\begin{array}{l}\text { Model yang menyatakan bahwa } \\
\text { antar peubah dalam model } \\
\text { yang diestimasi tidak saling } \\
\text { berhubungan }\end{array}$ \\
\hline $\begin{array}{l}\text { Tucker Lewis Index } \\
\text { (TLI) atau Non } \\
\text { Normed Fit Index } \\
\text { (NNFI) }\end{array}$ & $\begin{array}{l}\text { Ukuran kesesuaian model } \\
\text { terhadap ukuran NFI }\end{array}$ \\
\hline
\end{tabular}

Hipotesis yang diuji untuk pengujian model, adalah sebagai berikut:

H0 : $\Sigma$ model $=\Sigma(\theta)$ data $;$ model penelitian fit dengan data empirik

H1 : $\Sigma$ model $\neq \Sigma(\theta)$ data ; model penelitian tidak fit dengan data empirik

Kecocokan model secara keseluruhan dilihat berdasarkan ukuran kesesuaian model (Goodness of fit measures). Ukuran ini memberikan informasi apakah model yang dihasilkan dapat diterima atau tidak.

\section{HASIL}

\section{Karakteristik Responden}

Proses awal penelitian ini adalah melakukan analisis terhadap karakteristik responden berdasarkan jenis kelamin, usia, pendidikan terakhir, jabatan dan masa kerja. Dalam penelitian ini diambil 100 responden karyawan Keminfo yang telah mengikuti pelatihan yang diadakan oleh Keminfo. Teknik pengumpulan datanya adalah dengan indepth interview kepada responden untuk menjawab setiap butir pertanyaan demi untuk mendapatkan gambaran sesungguhnya terhadap persepsi responden. Jumlah responden terbagi dalam empat kelompok usia yaitu antara 20 tahun sampai 30 tahun, 31 tahun sampai 40 tahun, 41 tahun sampai 50 tahun dan lebih dari 51 tahun. Respoden sebagian besar 
adalah wanita dengan pendidikan sebagian besar adalah sarjana S1. Responden adalah karyawan Keminfo dengan jabatan yang bervariasi mulai dari analis, staf auditor, kasub, peneliti sampai staf dengan masa kerja rata-rata di bawah 10 tahun meski ada juga yang masa kerjanya lebih dari 10 tahun.

\section{Estimate (Loading factor)}

Gambar 2 merupakan hasil estimasi CFA standardized solution. Dapat diketahui bahwa terdapat 13 variabel teramati (observed variable). Karena beberapa variabel teramati mempunyai nilai standardized loading factor $>0,30$ maka variabel laten tersebut dapat dikatakan telah lolos uji validitas.

\section{Goodness of fit Model}

Dalam pengujian model secara keseluruhan, hasil kesesuaian model (Goodness of fit) yang diperoleh dalam penelitian ini dapat dilihat kriteria pada Tabel 3. Hasil pengolahan untuk pengujian goodness of fit menunjukkan bahwa dengan menggunakan pengujian chisquare diperoleh kesimpulan p-value $0.318>0,05$ sehingga Ho diterima dan Ha ditolak yang artinya model yang dihasilkan goodness of fit yang sudah menunjukkan bahwa model sudah baik. Selain itu SEM juga memberikan alternatif penggunaan indikator goodness of fit yang lain, yaitu dengan mengetahui kriteria RMSEA menghasilkan nilai $0,025 \leq 0,08$ yang artinya model yang dihasilkan sudah goodnes of fit.

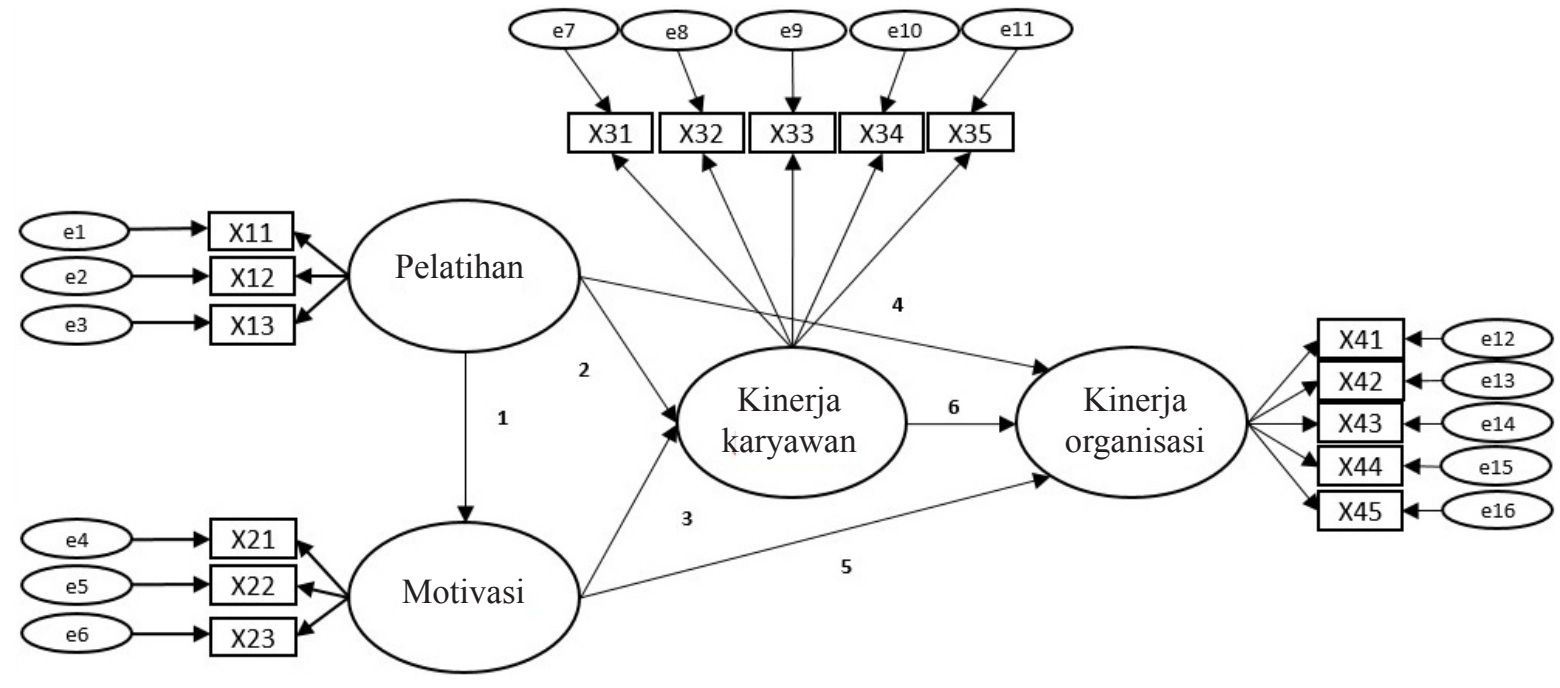

Gambar 1. Model pengukuran

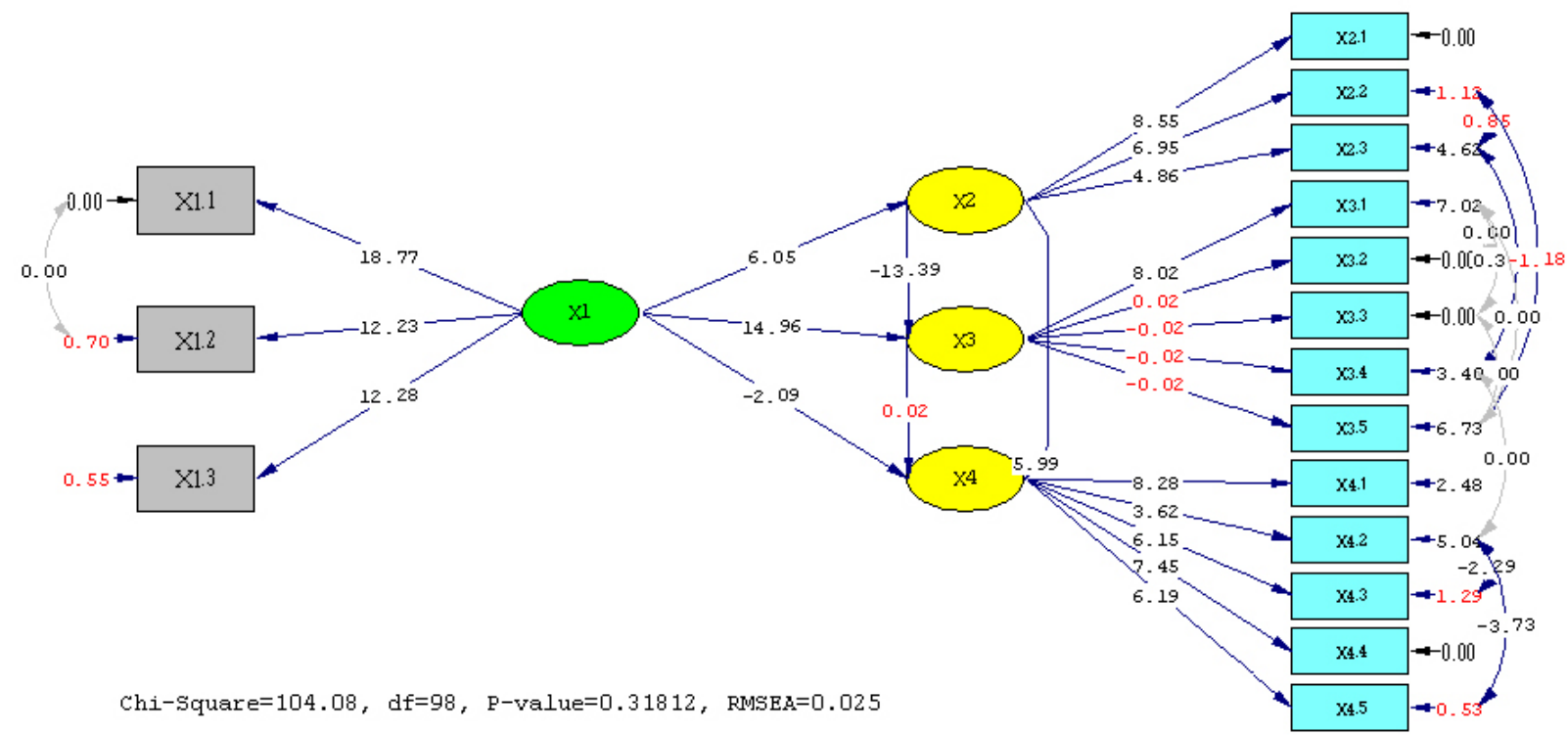

Gambar 2. Output LISREL 
Penggunaan kriteria goodness of fit yang lain, yaitu GFI, IFI, NFI dan CFI menghasilkan nilai $>0,9$. Artinya, model yang dihasilkan sudah goodness of fit. Karena hasil kesimpulan beberapa indikator menghasilkan kesimpulan model goodness of fit maka pengujian hipotesis teori dapat dilakukan.

Berdasarkan Tabel 3 untuk model struktural yang diperoleh, terlihat nilai X2 sebesar $=104,08$ (pada $\alpha$ $=5 \%$ dan $\mathrm{df}=98)$ dengan $\mathrm{p}$-value $=0,318$. Dilihat dari kriteria nilai X2, model struktural yang diperoleh memenuhi kriteria ideal dimana uji X2 yang diharapkan memiliki p-value $>0,05$. Hasil yang diperoleh p-value $=0,318>0,05$ menunjukkan bahwa hipotesis nol diterima dimana model penelitian yang diperoleh fit dengan data empirik yang digunakan.

Nilai RMSEA (Root Mean Square Error of Approximation) untuk model yang diteliti sebesar 0,025. Nilai RMSEA menunjukkan goodness of fit yang dapat diharapkan bila model diestimasi dalam populasi. Nilai RMSEA merupakan ukuran yang mencoba memperbaiki kecenderungan statistik Chisquare menolak model dengan jumlah sampel besar. Nilai RMSEA $\leq 0,05$ menunjukkan model fit dengan data (berdasarkan banyaknya derajat bebas/degrees of freedom dalam model). Dapat dikatakan model yang diperoleh dengan nilai RMSEA $=0,025$ memiliki tingkat kecocokan ( $f i t$ ) dengan data atau didukung oleh kondisi empirik.

Tabel 3. Goodness of fit

\begin{tabular}{|c|c|c|c|}
\hline $\begin{array}{c}\text { Goodness } \\
\text { of fit }\end{array}$ & $\begin{array}{l}\text { Cutt off } \\
\text { Value }\end{array}$ & Hasil & Kesimpulan \\
\hline $\begin{array}{l}\mathrm{X}^{2} \text { - Chi- } \\
\text { square }\end{array}$ & $\begin{array}{c}\text { Diharapkan } \\
\text { kecil }\end{array}$ & 104,08 & $\begin{array}{c}\text { goodness } \\
\text { of fit }\end{array}$ \\
\hline Significance & $\geq 0.05$ & $\mathrm{P}=0,318$ & \\
\hline RMSEA & 0.08 & 0,025 & $\begin{array}{c}\text { goodness } \\
\text { of fit }\end{array}$ \\
\hline GFI & Mendekati 1 & 0,95 & $\begin{array}{c}\text { goodness } \\
\text { of fit }\end{array}$ \\
\hline IFI & Mendekati 1 & 1,00 & $\begin{array}{c}\text { goodness } \\
\text { of fit }\end{array}$ \\
\hline NFI & Mendekati 1 & 0,93 & $\begin{array}{c}\text { goodness } \\
\text { of fit }\end{array}$ \\
\hline CFI & Mendekati 1 & 1,00 & $\begin{array}{c}\text { goodness } \\
\text { of fit }\end{array}$ \\
\hline
\end{tabular}

Goodness of fit Index (GFI) merupakan ukuran kesesuaian model secara deskriptif. Nilai GFI yang direkomendasikan untuk menyatakan model yang diteliti fit adalah $>0,90$. Dilihat dari kriteria nilai Goodness of fit Index (GFI) sebesar 0,95 dapat dikatakan model yang diperoleh memiliki tingkat kesesuaian yang baik secara deskriptif.

Normed Fit Index (NFI) merupakan ukuran perbandingan antara proposed model (model yang diajukan) dengan null model. Nilai NFI yang direkomendasikan untuk menyatakan model yang diteliti fit adalah $>0,90$. Dilihat dari kriteria nilai NFI (Normed Fit Index) model penelitian adalah 0,93 dapat dikatakan model yang diperoleh memiliki tingkat kecocokan (fit) yang baik dengan data.

Hasil pengujian model secara keseluruhan telah memenuhi ukuran kesesuaian model (Goodness of fit). Dengan demikian dapat dikatakan model baik dan dapat diterima. Berdasarkan kriteria yang dapat dipenuhi dari model penelitian ini, dapat dikatakan model yang diperoleh dapat digunakan untuk menjelaskan hubungan antar model yang diteliti. Artinya, model yang diperoleh dapat menjelaskan hubungan dan pengaruh pelatihan dan motivasi terhadap kinerja karyawan dan kinerja organisasi Keminfo.

Untuk menguji pengaruh variabel yang dihipotesiskan diatas digunakan uji t dengan kriteria uji untuk $\bar{\alpha}$ penelitian sebesar 0,05 , nilai untuk batas dinyatakan uji signifikan adalah 1,96. Diperoleh hasil pengujian pengaruh dari pelatihan, motivasi, kinerja karyawan dan kinerja organisasi serta pengaruh variabel pelatihan dan motivasi terhadap kinerja karyawan dan kinerja organisasi signifikan secara pengujian statistik karena nilai t-hitung untuk setiap pengujian lebih besar dari ttabel 1,96 .

\section{Pengaruh Pelatihan Terhadap Motivasi}

Hipotesis pertama menyatakan X1 berpengaruh positif langsung terhadap X2. Dari hasil pengolahan diperoleh koefisien estimasi sebesar 0.290 yang artinya semakin tinggi X1 akan semakin tinggi X2 secara langsung dan sebaliknya. Hasil ini menunjukkan bahwa hipotesis teori yang diajukan terbukti dengan nilai tsatistik sebesar 6,050 > t-table 1,96 yang artinya Ho ditolak sehingga dapat disimpulkan bahwa terdapat pengaruh positif dari X1 terhadap X2 secara signifikan. 
Dari hasil penelitian didapatkan bahwa pelatihan berpengaruh secara signifikan terhadap motivasi. Dalam hal ini pelatihan merupakan wadah untuk membangkitkan motivasi diri karyawan. Apabila karyawan diberikan pelatihan di kantor, maka karyawan akan merasa percaya diri dalam menjalankan tugastugasnya di kantor. Semakin banyak pelatihan yang diberikan maka semakin banyak ilmu dan pengetahuan yang di dapatkan oleh karyawan, sehingga karyawanpun akan lebih mudah dalam menyelesaikan pekerjaannya.

\section{Pengaruh Pelatihan Terhadap Kinerja Karyawan}

Hipotesis kedua menyatakan X1 berpengaruh positif langsung terhadap X3. Dari hasil pengolahan diperoleh koefisien estimasi sebesar 0,240 yang artinya semakin tinggi X1 akan semakin tinggi X3 secara langsung dan sebaliknya. Hasil ini menunjukkan bahwa hipotesis teori yang diajukan terbukti dengan nilai tsatistik sebesar 14,960 > t-table 1,96 yang artinya Ho ditolak sehingga dapat disimpulkan bahwa terdapat pengaruh positif dari X1 terhadap X3 secara signifikan.

Penelitian juga menyatakan X1 berpengaruh negatif tidak langsung terhadap X3. Dari hasil pengolahan diperoleh koefisien estimasi sebesar $-0,020$ yang artinya semakin tinggi $\mathrm{X} 1$ akan semakin tinggi $\mathrm{X} 2$ secara langsung dan sebaliknya. Hasil ini menunjukkan bahwa hipotesis teori yang diajukan terbukti dengan nilai tsatistik sebesar 5,350 > t-table 1,96 yang artinya Ho ditolak sehingga dapat disimpulkan bahwa terdapat pengaruh negatif tidak langsung dari X1 terhadap X3 secara signifikan.

Hal tersebut mengidentifikasikan bahwa pelatihan berpengaruh positif terhadap kinerja karyawan. Karyawan sangat membutuhkan pelatihan agar dapat lebih baik kinerjanya di perusahaan. Penelitian ini menunjukkan bahwa semakin baik pelatihan yang diberikan maka kinerja pegawai di Keminfo juga akan semakin tinggi. Akan tetapi, perubahan kinerja karyawan tidak hanya disebabkan oleh pelatihan saja. Pendidkan dan pelatihan adalah salah satu faktor pembangkit semangat kerja karyawan. Oleh karena itu dapat juga dikatakan bahwa pelatihan berpengaruh negatif secara tidak langsung.

\section{Pengaruh Motivasi Terhadap Kinerja Karyawan}

Hipotesis ketiga menyatakan X2 berpengaruh negatif langsung terhadap X3. Dari hasil pengolahan diperoleh koefisien estimasi sebesar $-0,055$ yang artinya semakin tinggi X2 akan semakin rendah X3 secara langsung dan sebaliknya. Hasil ini menunjukkan bahwa hipotesis teori yang diajukan terbukti dengan nilai statistik sebesar 13,390 > t-table 1,96 yang artinya Ho ditolak sehingga dapat disimpulkan bahwa terdapat pengaruh negatif dari X2 terhadap X3 secara signifikan.

Hasil penelitian menunjukkan bahwa motivasi tidak sepenuhnya berpengaruh terhadap kinerja karyawan. Dalam hal ini motivasi hanya berperan sebagai pendorong karyawan dalam bekerja lebih giat. Apabila karyawan diberikan motivasi yang positif oleh pimpinan, maka karyawan pasti akan merasa dihargai sehingga karyawanpun senang dalam bekerja. Oleh karena itu, dapat disimpulkan bahwa motivasi tidak berpengaruh terhadap kinerja karyawan.

\section{Pengaruh Pelatihan Terhadap Kinerja Organisasi}

Hipotesis keempat menyatakan X1 berpengaruh negatif langsung terhadap X4. Dari hasil pengolahan diperoleh koefisien estimasi sebesar -0,070 yang artinya semakin tinggi X1 akan semakin rendah X4 secara langsung dan sebaliknya. Hasil ini menunjukkan bahwa hipotesis teori yang diajukan terbukti dengan nilai statistik sebesar 2,090 > t-table 1,96 yang artinya Ho ditolak sehingga dapat disimpulkan bahwa terdapat pengaruh negatif dari X1 terhadap X4 secara signifikan. Selain itu penelitian menyatakan $\mathrm{X} 1$ tidak berpengaruh positif tidak langsung terhadap X4. Hasil ini menunjukkan bahwa hipotesis teori yang diajukan terbukti dengan nilai statistik sebesar 0,370<t-table 1,96 yang artinya Ho diterima sehingga dapat disimpulkan bahwa tidak terdapat pengaruh positif tidak langsung dari X1 terhadap X4 secara signifikan.

Dalam hal hubungannya dengan kinerja organisasi, pelatihan berpengaruh negatif. Kinerja organisasi dapat tercapai maksimal tidak hanya karena karyawannnya berkualitas. Terdapat beberapa faktor yang menunjang perusahaan dalam pembangunan perusahaannya dan salah satunya adalah pelatihan. Oleh karena itu, dapat dikatakan bahwa pelatihan hanya berperan sebagai salat satu faktorpenting dalam peningkatan kinerja organisasi. Secara penelitian, pelatihan tidak berpengaruh secara langsung terhadap kinerja organisasi. 


\section{Pengaruh Motivasi Terhadap Kinerja Organisasi}

Hipotesis kelima menyatakan X2 berpengaruh positif langsung terhadap X4. Dari hasil pengolahan diperoleh koefisien estimasi sebesar 0,240 yang artinya semakin tinggi X2 akan semakin tinggi X4 secara langsung dan sebaliknya. Hasil ini menunjukkan bahwa hipotesis teori yang diajukan terbukti dengan nilai statistik sebesar 5,990 > t-table 1,96 yang artinya Ho ditolak sehingga dapat disimpulkan bahwa terdapat pengaruh positif dari X2 terhadap X4 secara signifikan. Pada penelitian, diketahui juga bahwa X2 tidak berpengaruh positif tidak langsung terhadap X4. Hasil ini menunjukkan bahwa hipotesis teori yang diajukan terbukti dengan nilai statistik sebesar $0,020<\mathrm{t}$-table 1,96 yang artinya Ho diterima sehingga dapat disimpulkan bahwa tidak terdapat pengaruh positif tidak langsung dari X2 terhadap X4 secara signifikan.

Peneliti mengidentifikasikan bahwa motivasi berpengaruh positif terhadap kinerja organisasi secara signifikan. Hal ini menunjukkan bahwa semakin tinggi motivasi maka kinerja Keminfo juga akan semakin tinggi. Melalui hasil analisis disimpulkan pula bahwa kinerja organisasi dapat tercapai maksimal tidak hanya karena motivasi saja. Terdapat beberapa faktor yang menunjang perusahaan dalam pembangunan perusahaannya dan salah satunya adalah motivasi karyawan. Oleh karena itu, dapat dikatakan bahwa motivasi tidak berpengaruh secara langsung terhadap kinerja organisasi.

\section{Pengaruh Kinerja Karyawan Terhadap Kinerja Organisasi}

Hipotesis keenam menyatakan X3 tidak berpengaruh positif langsung terhadap X4. Hasil ini menunjukkan bahwa hipotesis teori yang diajukan terbukti dengan nilai statistik sebesar $0,019<\mathrm{t}$-table 1,96 yang artinya Ho diterima sehingga dapat disimpulkan bahwa terdapat tidak ada pengaruh positif dari X3 terhadap X4. Tingginya kinerja karyawan ternyata tidak berpengaruh positif terhadap tingginya kinerja organisasi. Dalam memaksimalkan kinerja Keminfo, terdapat beberapa faktor yang harus saling mendukung, dalam arti kinerja Kominfo akan tinggi jika kinerja karyawannya baik dan faktor lainnya juga terkolaborasi secara baik. Hal inilah yang membuat variabel penelitian secara tidak langsung memengaruhi kinerja organisasi.

\section{Implikasi Manajerial}

Sesuai hasil penelitian terhadap hubungan antara variabel pelatihan dan motivasi terhadap kinerja karyawan dan kinerja organisasi, maka perlu ditekankan pentingnya membangkitkan motivasi diri karyawan agar merasa percaya diri dalam menjalankan tugastugasnya di kantor. Pelatihan adalah salah satu faktor pembangkit semangat kerja karyawan.

Beberapa hal yang dapat menjadi prioritas adalah Keminfo perlu melakukan variasi pelatihan sesuai dengan minat karyawan dan memberikan motivator positif dalam rangka menumbuhkan minat karyawan untuk meningkatkan kualitasnya. Pelatihan tidak hanya bersifat monoton atau sesuai jobdesk di kantor saja, akan tetapi Keminfo dapat membebaskan karyawannya unuk mengambil pelatihan sesuai minatnya. Pelatihan dalam hal ini hanya berperan sebagai salat satu faktor penting dalam peningkatan kinerja Keminfo karena Keminfo memiliki sejumlah program-program yang dilaksanakan untuk kepentingan kinerja perusahaan. Peningkatan kinerja karyawan tidak hanya serta merta dengan pelatihan saja, faktor-faktor lain juga dapat membuat kompetensi dan kualitan karyawan Keminfo menjadi semakin meningkat.

\section{KESIMPULAN DAN SARAN}

\section{Kesimpulan}

Variabel pelatihan secara signifikan berpengaruh positif secara langsung terhadap kinerja karyawan Keminfo. Variabel inipun juga berpengaruh signifikan terhadap motivasi. Untuk variabel motivasi tidak berpengaruh positif secara signifikan terhadap kinerja karyawan. Variabel ini dirujuk untuk memperbaiki dan meningkatkan kinerja karyawan. Pelatihan secara tidak langsung tidak mempunyai pengaruh positif terhadap kinerja karyawan dan kinerja organisasi. Begitu juga dengan motivasi, variabel ini tidak berpengaruh positif tidak langsung terhadap kinerja organisasi.

Komponen pelatihan mempunyai pengaruh penting terhadap kinerja pegawai dengan bukti bahwa mayoritas responden menjawab setuju tentang adanya pengaruh pelatihan terhadap kinerja pegawai. Komponen pelatihan yang terdiri dari kebutuhan, pengelolaan dan evaluasi pelaksanaanya dirasa cukup efektif pelaksanaannya demi meningkatkan motivasi. 
Atasan memberikan motivasi kepada pegawai didasari untuk peningkatan kinerja. Motivasi dilakukan dengan berbagai cara baik melalui, peningkatan gaji pegawai, pengadaan reward dan punishment maupun penciptaan lingkungan kerja yang baik antara sesama pegawai. Hal tersebut dilakukan untuk membuat pegawai Keminfo lebih semangat dan merasa nyaman bekerja serta terdorong untuk melaksanakan tugasnya dengan baik.

Variabel kinerja pegawai tidak berpengaruh positif dan signifikan terhadap kinerja organisasi. Hal ini bisa diartikan kinerja pegawai sudah cukup baik. Bila dilihat secara simultan, hal tersebut tidak lepas dari peranan pelatihan dan motivasi. Faktor pendukung lainnya juga dibutuhkan dalam rangka untuk meningkatkan kinerja pegawai yang juga akan meningkatkan kinerja Keminfo. Semua itu harus berjalan secara kontinu dan terarah. Dengan pemberian pelatihan yang baik dan berkesinambungan serta pemberian motivasi yang tepat dapat membuat kinerja karyawan lebih tinggi dan kinerja organisasi lebih baik.

\section{Saran}

Dengan adanya pelatihan terindikasi pegawai dapat melaksakan pekerjaan dengan baik, dengan pelatihan pula dapat merubah sikap, attitude dan disiplin pegawai. Untuk meningkatkan kinerja pegawai di Keminfo, pemerintah perlu juga mengadakan kajian tentang penerapan pelatihan bagi pegawai sesuai dengan kebutuhannya dan mengadakan pelatihan yang sesuai dengan kompetensi yang harus dimiliki oleh pegawai Keminfo.

Untuk meningkatkan motivasi pegawai Keminfo sebaiknya pemerintah menginformasikan dan menetapkan indikator insentif agar lebih transparan. Motivasi para pegawai dapat ditingkatkan melalui reward berupa promosi jabatan, kenaikan gaji dan evaluasi kinerja. Pemerintah hendaknya menetapkan kebijakan atau langkah yang strategis untuk memotivasi pegawai dalam menyelesaikan pekerjaannya dengan baik, tepat, dan akurat sesuai dengan tujuan yang ditetapkan, serta memberikan sanksi (punishment) yang tegas bagi pegawai yang kurang disiplin dan tidak dapat menyelesaikan pekerjaannya dengan baik dan tepat.

\section{DAFTAR PUSTAKA}

Budiartha IGN, Bagia IW, Suwendra IW. 2015. Pengaruh pelatihan dan motivasi kerja terhadap produktivitas kerja karyawan. E-Jurnal Bisma Universitas Pendidikan Ganesha 3(1):1-10.

Dartha IK. 2010. Pengaruh pendidikan dan pelatihan (diklat) terhadap kinerja PNS pada Sekda Kota Malang. Jurnal Ekonomi Modernisasi 6(2):140 160.

Dewi Sri K, Laras T. 2014. Pengaruh pelatihan, motivasi kerja dan lingkungan kerja terhadap kinerja karyawan Koperasi Mahasiswa (KOPMA) di Kabupaten Sleman. Jurnal Bisnis dan Ekonomi 5(1):48-72.

Ernanto B, Baga LM, Sunarti E. 2015. Pengaruh penerapan budaya perusahaan terhadap motivasi kerja dan kinerja karyawan di PT. Rekayasa Industri. Jurnal Aplikasi Bisnis dan Manajemen 1(1):1-11.

Fatihin Amirul. 2014. Pengaruh pelatihan dan budaya organisasi terhadap efektifitas kinerja karyawan. Jurnal STAIN Kudus 2(1):140-154.

Hersey P, Blanchard KH. 1993. Management for organizational Behavior. Ed ke-6. Singapore: Prentice hall

[Kominfo] Kementerian Komunikasi dan Infromatika. 2014. Laporan Tahunan 2014: Мепијu Masyarakat Informasi Indonesia. Jakarta: Kominfo

Keith D, Newstrom JW. 2000. Perilaku Dalam Organisasi. Ed Ke-7. Jakarta: Erlangga

Martoyo K S. 1992. Manajemen Sumber Daya Manusia. Yogyakarta: BPFE.

Mangkunegara A P. 2009. Manajemen Sumber Daya Manusia. Bandung: Rosdakarya.

Nazar Fuad, Astuti Endang S, Riza Muhammad F. 2014. Pengaruh pendidikan dan pelatihan terhadap motivasi kinerja karyawan PT BTPN Malang. Jurnal Admnistrasi Bisnis 13(1):1-9.

Rivai dan Basri. 2005. Performance Appraisal. Ed ke-1. Jakarta: PT. Raja Grafindo Persada.

Pakpahan Edi S, Siswidiyantoo, Sukanto. 2014. Pengaruh pendidikan dan pelatihan terhadap kinerja karyawan. Jurnal Administrasi Publik 2(1):116-121.

Pemerintah Republik Indonesia. 2014. UndangUndang Republik Indonesia Nomor 05 Tahun 2014 tentang Aparatur Sipil Negara. Jakarta: Seketaris Negara. 
Pojoh Tirza P, Tewal Bernhard, Moniharapon S. 2014. Pengaruh pendidikan dan pelatihan (diklat) terhadap kinerja karyawan pada PT PLN (Persero) Suluttenggo. Jurnal EMBA 2(4):424434.

Radhian WF, Hubeis M, Kuswanto S. 2016. Kebutuhan karyawan pada unit fungsional kebun PTPN IV Medan Sumatra Utara. Jurnal Aplikasi Bisnis dan Manajemen 2(2):118-126.

Rapaeni Y. 2013. Pengaruh pendidikan dan pelatihan produktivitas guru Yayasan Jihadiyah Palembang. Jurnal Ekonomi dan Informasi Akutansi (JENIUS) 3(3):216-229.

Rumondor VW. 2013. Motivasi, disiplin kerja dan kepemimpinan terhadap produktivitas kerja pada bagian kepegawaian dan diklat daerah Minahasa Selatan. Jurnal EMBA 1(4): 1042-1052

Sahanggamu PM, Mandey SL. 2014. Pengaruh pelatihan kerja, motivasi dan disiplin kerja terhadap kinerja karyawan pada PT. Bank Perkreditan Rakyat Dana Raya. Jurnal EMBA 2(4):514-523.

Satria RO, Kuswara A. 2013. Pengaruh motivasi dan pelatihan terhadap kompetensi kerja serta implikasinya pada produktivitas pegawai Dinas Perhubungan Kota Bandung. Jurnal Ekonomi, Bisnis dan Enterpreneurship 7(2):74-83.

Setiana Aniva A, Siswandoko Tjajuk. 2009. Analisis pengaruh pendidikan dan pelatihan serta motivasi terhadap kinerja karyawan PT. Aggrek Mobilindo Bekasi. Jurnal Ekonomi dan Industri 2(14): 36-42

Sobandi B. 2006. Desentralisasi dan Tuntutan Penataan Kelembagaan Daerah. Bandung: Bandung.

Suharjo B. 2007. Perbandingan metode pendugaan parameter dalam pemodelan persamaan structural. Jurnal Matematika IPB 12(1):88101

Suryana, Siti H, Muhammad IT. 2010. Pengaruh kepemimpinan dan motivasi kerja terhadap kepuasan karyawan dan kinerja perusahaan (studi kasus di divisi tambang PT. Inco Sorowoko). Jurnal Universitas Hasanudin 2011:1-16.

Yusuf M. 2015. Pengaruh diklat dan displin kerja terhadap produktivitas kerja pegawai pada dinas kehutanan dan perkbunan Kabupaten Bireuen. Jurnal Kebangsaan 4(7): 27-34. 